UDK: 373.2.016:[37.015·31:17.022.1](497.11+497.5) Professional paper

\title{
OBJECTIVES IN MODERN PRESCHOOL PROGRAMMES (GURRICULA) IN THE REPUBLIC OF SERBIA AND THE REPUBLIC OF CROATIA WITH THE PURPOSE OF MORAL DEVELOPMENT OF PRESCHOOL CHILDREN
}

Ivana Apostolović

Jagodina

Serbia

ivanaapostolovic94@hotmail.rs 


\begin{abstract}
In thispaper, we analyze and compare the content of current preschool programmes (curricula) in the Republic of Serbia and the Republic of Croatia through a detailed presentation of the goals of moral development and upbringing of preschool children in them. The research was performed using a descriptive method, and the content analysis procedure was applied in the paper. The results of the research, presented textually and tabulary, indicate that in the Republic of Serbia and the Republic of Croatia in all three preschool programmes (curricula), there are goals related to moral development and upbringing of the child, but there are no specific goals of moral development, yet we recognize them within areas/aspects of child development, common educational goals, general goals, child welfare support goals or individual goals.
\end{abstract}

Key words: preschool programme (curriculum), goals of moral development and upbringing, child. 


\section{INTRODUCTION}

In the Republic of Serbia, the education of children in preschool institutions takes place in an organized manner which contributes to the all-round development of the overall children's potential / welfare, and thus to the moral development and upbringing. The organization of educational work in preschool institutions provides quality conditions for development and learning, creates a climate that promotes social and emotional development, and a stimulating and flexible environment that, through the goals of moral development and education in current programme documents in the Republic of Serbia and the Republic of Croatia, opens wide opportunities for directing socio-moral education in the direction desirable for the child and family, as well as the society, in accordance with the achievements of the 21st century.

Programme documents regulating the field of preschool education are the General Foundations of the Preschool Programme (2006) and Preschool curriculum framework - Years of Ascent (2018) in the Republic of Serbia, and the National Curriculum for Early and Preschool Education (2014) in the Republic of Croatia.

The task of the research was to determine whether the goals of moral development and education of children in preschool programmes (curricula) are derived from the general goals of education or are concretized as individual (special) goals. It is hypothesized that in preschool programmes (curricula) in the Republic of Serbia and the Republic of Croatia, the goals of moral development and education of early ages derive from the general goals of education.

\section{MORAL DEVELOPMENT AND EDUCATION OF PRESCHOOL CHILDREN AS AN IMPORTANT ASPECT OF THEIR OVERALL DEVELOPMENT}

Moral development and education are long and ongoing processes that start in the family with the socialization of the child, i.e. his/her integration into the existing family, and later social, context by learning and "absorbing" patterns of behaviour from its environment on a daily basis. Behaviours that the child learns in the family are the basis of its morality, which, undeveloped and incomplete, get stronger and corrected in preschool. When the child starts school, the process of moral education continues, with the child learning and adopting new patterns and models of behavior through the educational work and content that the school offers.

Theories of morality and moral development of children can be studied from different aspects. A significant contribution to the interpretation of the 
morality of the child was made by prominent scientists: J. Piaget, L. Kohlberg, K. Baier, D. Elkind, M. L. Hoffman, A. Bandura. The most famous conceptions of moral development are Freud's psychoanalytic theory, as well as Kohlberg's and Piaget's theories of moral development. There is also a notable contribution of contemporary authors who have dealt with the moral development of the child in the Republic of Serbia: Miočinović, Antonijević, Popović, Radašin, Vlahović, Potkonjak, etc. Their contribution to the explanation, interpretation and broad understanding of the concept of morality and moral development of children is significant even today. Today, official science confirms that the postulates of these reputable people in the last two decades have created important works, that is, empirical research, supported by new knowledge in science, which has brought different views on the child's world (in preschool pedagogy, family pedagogy, developmental and child psychology, sociology, philosophy, culturology, etc.).

Authors who have studied moral development point out that moral education is "building a moral personality, one of the most important areas of education and upbringing; the main goal consists in developing the qualities of a moral personality: moral consciousness (moral education), moral feelings (turning moral consciousness into beliefs, motives for moral actions), moral will (basis for moral actions, behavior), moral judgment (moral conscience, critical attitudes towards one's own and others' moral actions)" (Pijanović et al., 1996, 299). The author Antonijević states that "Moral development refers to the process of learning and understanding morality, as well as the development of habits of moral behavior, which takes place from an early age. In the field of moral development, morality is determined "through principles relating to the ways in which each individual should behave in relation to the other, in relation to the justice, welfare and rights of the other" (Antonijević, 2013, 192). The author Hurlock states that "for the development of morality in preschool children, contacts with the wider social environment are important. "Parents have the greatest influence on the child, as well as the child's peers, but it is of great importance that the child comes into contact with adults who are not members of the family in which the child grows up" (Hurlock, as cited in Kamenov, 1997, 41). Kamenov also concludes that "the basic path of development of children's morality nevertheless remains the process of their socialization in the broadest sense of the word, which means that expanding the social horizons of children, and inclusion in increasingly complex networks of social relations, is a condition for the gradual adoption of moral norms" (Kamenov, 1997, 42). The moral development of a preschool child 
is an important determinant of the development of its overall potentials. The development of morality starts at the child's earliest age and is closely related to the process of socialization of the person in the broadest sense of understanding. The moral development of a child has an ascending path and is not limited in time. The child learns morals in the family, then in the preschool age, and later in school. We can say that the morality of preschool children is still in the process of shaping.

Every society ideologically strives in the global sense to pass on to the youth, through the basic institutions of society, the basic moral values promoted by every humane society, as well as special values that are the specificity of society (therefore it sets them, defines them as separate goals or priorities, in the preschool or school programme / curriculum, in legal documents, etc.). Starting from the preschool institution, and later from other official institutions of the society, modern educational programmes are designed, the implementation of which creates quality conditions for the welfare of the child, thus developing the morality of the child in the direction desired for the child (entity) as an individual in society, as well as for the family (microsystem) which is still the most important instance of society, and for society as a whole (macrosystem).

\section{OBJECTIVES IN PRESCHOOL PROGRAMMES IN THE REPUBLIC OF SERBIA WITH THE PURPOSE OF MORAL DEVELOPMENT OF PRESGHOOL CHILDREN}

The first programme document in the Republic of Serbia, General Foundations of the Preschool Programme (2006), starts from the child, their needs, development potentials and holistic nature. The programme states: "The essential determinant is that the child is a value in itself, that it carries developmental potentials, that it is a factor in its own development, socialization and upbringing (Bylaw on Preschool...., 2006, 13). With its conception and philosophy of upbringing, the document emphasizes organized forms of institutional preschool education in preschool institutions, in order to encourage the complete and moral development of the child. Within the complete understanding of the child's personality, moral development and moral education are encouraged in this programme document within the the overall development during the entire preschool period.

The General Foundations of the Preschool Programme includes two models of preschool education, Model A and Model B, as well as Common features of the model of preschool upbringing and education. The main characteristic of both programme 
models is that they are goal-oriented towards the child as a being, which indicates the humanistic orientation of the programme. The child is recognized as a valuable being and takes a central place in the programme.

Model A highlights the areas of development, while Model B highlights aspects of development. Areas of development in Model A are: getting to know and mastering yourself; developing relationships and knowledge about others; building knowledge about the environment and ways of affecting it. Aspects of development in Model B are: physical development; socio-emotional development; cognitive development and the development of communication and children's creativity (Bylaw on Preschool...., 2006). We note that moral development is not highlighted in this programme document as a separate aspect of child development. This part is encouraged and developed within a holistic approach to the child, continuously throughout the preschool period, starting from the youngest to the oldest preschool age. Moral development and moral education of a preschool child is presented through the common goal orientations of Model A and Model B.

In the Common educational goals in both programme models, we find those that are closely related to the moral development of the preschool child:

- "gaining a positive self-image;

- developing trust in yourself and others;

- encouraging independence, individual responsibility and authenticity of expression and action;

- developing social and moral values in accordance with the humane and tolerant values of a democratically organized society sensitive to family, cultural and religious differences;

- cultivating children's emotions and nurturing the relationship of nonviolent communication and tolerance;

- preparing children for the upcoming transitional and more complex periods of life (preparation and adaptation for going to kindergarten; to school; for recreational visits, etc.);

- developing awareness of the importance of protecting and preserving the natural and social environment" (Bylaw on Preschool..., 2006, 13).

According to Model A, in the section Conception of Childhood and Child Upbringing, the moral development of the child is reflected in the starting points of the programme, which is that "the child needs to be what it is, to grow, develop; the child is a unique being. The development of a child is not achieved by separately affecting certain sides of the personality or aspects of development; the child is a social being and needs to understand itself and the world around it" (Bylaw on Preschool..., 2006, 25). 
According to Model A, the common goal of preschool education can be translated into three groups of goals, which also refer to the three areas of child development and upbringing. The goals of preschool education are for children to:

- "discover and get to know themselves

- develop relationships and gain experiences and knowledge about other people

- learn about the world around them and develop ways of affecting it" (Bylaw on Preschool..., 2006, 28). The first two goals or areas of development refer to moral development.

The first goal in Model A, through which moral development permeates, is for children to discover and get to know themselves. This includes the following specific objectives:

- "exploring and accepting its strengths and limits as the basis of selfconfidence

- expanding its strengths and limits, by affecting the environment and interacting with others" (Bylaw on Preschool..., 2006, 28).

The second goal of preschool education in Model A, which includes moral development, is for the child to develop relationships and gain experiences and knowledge about other people. This includes the following specific objectives:

- "building openness and trust towards others based on self-confidence

- getting to know and understanding the rules of behaviour in the group and the environment and building basic moral norms

- learning to recognize and respect the needs and feelings of others

- developing friendly and cooperative relationships with peers and adults

- expanding experiences and deepening the understanding of social and cultural reality (human race, social institutions, customs, traditions, cultural differences)

- using and developing different ways of communicating with other people

- learning to listen and respect the ideas and opinions of others, but also to oppose their point of view" (Bylaw on Preschool..., 2006, 28).

According to Model B, the ultimate purpose of preschool education is the optimal and harmonious development of mental, spiritual and physical qualities and strengths of a person and its realization, in which the child will achieve personal happiness and realize itself as a person in a given sociocultural context of relationships. This purpose is in line with the general humanistic and democratic 
aspirations in our society (Bylaw on Preschool..., 2006). Spiritual development implies the moral development and upbringing of the child. The main (common) goal according to Model B is the complete development of the overall potential of the child and progress in each of its aspects, with qualitative improvement of the areas that it already possesses. Within the overall development, moral development is also encouraged. The specific objectives presented in Model B that determine the children's moral development are:

- "forming an emancipated personality, aware of themselves and their potentials, social and natural environment

- forming a personality that is constructive, satisfied and filled with optimism in relation to itself, other people and life in general

- forming a personality that is guided by human values and aspirations" (Bylaw on Preschool..., 2006, 50).

The second official and current programme document, which systematically regulates preschool education in the Republic of Serbia, is the Preschool Curriculum Framework - Years of Ascent (2018). The concept of the programme is based on "modern theoretical assumptions about childhood, learning and development of children at an early age", as well as on the assumption that "traditional foundation of preschool education in Serbia is based on humanistic values, integrated approach to care, upbringing and education, respect for the age specifics of the child and the leading role of play in the child's learning and development" (Preschool Curriculum Framework..., 2018:10). The Preschool Curriculum Framework sees the child as "a unique and complete being; competent and rich in potentials; active participant in the peer and adult community; dedicated to learning; creative; being of playing" (Preschool Curriculum Framework..., 2018, 13-14).

The Preschool Curriculum Framework highlights the following objectives:

- "General objectives of the Curriculum Framework

- Child-centered goals of preschool education: supporting the child's welfare" (Preschool Curriculum Framework..., 2018, 17-18).

This preschool programme defines the General Objectives of the Curriculum Framework, within which the moral development of children is recognized through several objectives:

- "that all preschool children, through the support of their welfare, have equal opportunities for learning and development

- that, by participating in the programmes, children have the opportunity to be happy, to feel satisfied, fulfilled and accepted, to build relationships of trust and respect, closeness and friendship 
- that children develop dispositions for lifelong learning such as openness, curiosity, resilience, reflexivity, perseverance, self-confidence as a capable "student" and a positive personal and social identity, thus laying the foundations for the development of educational competencies

- that children, by participating in the programmes, have the opportunity to get to know, research and review different areas of human cognition and action, different cultural products and ways of building and expressing meaning" (Preschool Curriculum Framework..., 2018, 17).

The document presents the Goals of preschool education aimed at the child: supporting the child's welfare. "The goals aimed at the child are formulated as longterm goals of support of welfare and concretized at the level of a real programme" (Preschool Curriculum Framework..., 2018, 12). In the Republic of Serbia, institutional pre-school upbringing and education of children should contribute to the general welfare of the child. The programme clearly states the goal of this programme: "The goal of the preschool education programme is to support the welfare of the child. Welfare is a multidimensional construct that unites the understanding of the holistic nature of development, the integrity of the process of care, upbringing and education, integrated learning of a preschool child" (Preschool Curriculum Framework..., 2018, 18). This clearly indicates the humanistic value orientation of the programme.

In this programme, Goals of preschool education aimed at the child: supporting the child's welfare, refer to:

- "support for the personal welfare of the child

- support for the active welfare of the child

- support for the social welfare of the child" (Preschool Curriculum Framework..., 2018, 18).

Within the Support for the personal welfare of the child, the goals that determine the child's moral development are:

- "developing awareness and care for your body and yourself

- developing self-regulation as internal control, the ability to put aside desires

- accepting demands and finding alternatives

- developing instrumental and psychological independence

- developing identity and self-acceptance

- developing emotional competence as the ability to experience and express a wide range of emotions, regulate and control emotions and understand one's own and others' emotions" (Preschool Curriculum Framework..., 2018, 18). 
Within the Support for the active welfare of the child, the goals related to the moral development of the child are:

- "developing dispositions for learning such as perseverance, curiosity, initiative and creativity, openness to cooperation, responsibility

- developing resilience to stress and challenges and the ability to take a constructive approach to problems and change

- building meaning and purpose in life through a deeper understanding of the basic manifestations of human life, values and beauty of people and their work" (Preschool Curriculum Framework..., 2018, 18-19).

Within the Support for the social welfare of the child, the goals that determine the child's moral development are:

- "developing a positive cultural and social identity and satisfaction and pride by belonging to different communities (peer, family, local, national, global)

- developing social competence as the ability of emotional connection and empathy, successful social communication and cooperation

- developing moral values and norms and the ability of moral reasoning, fairness and respect for differences

- developing altruism, traits of humaneness such as helpfulness, empathy, tolerance, kindness, solidarity

- developing awareness of the interconnectedness of people and nature and care for the environment

- developing a proactive attitude towards life and the environment" (Preschool Curriculum Framework..., 2018, 19).

The Goals of preschool education aimed at the child: supporting the child's welfare highlight the Specifics of key educational competencies for lifelong learning in preschool education which should be developed in children. Moral development in these competencies is directly stated through two competencies:

- "social and civic competencies

- cultural awareness and expression" (Preschool Curriculum Framework..., 2018, 21). 


\section{OBJECTIVES IN THE PRESCHOOL CURRICULUM IN THE REPUBLIC OF CROATIA WITH THE PURPOSE OF MORAL DEVELOPMENT OF PRESCHOOL CHILDREN}

The official programme document that systematically regulates preschool education in the Republic of Croatia is the National Curriculum for Early and Preschool Education (2014). The starting points of this curriculum are "the principles of freedom, openness and diversity, which should be reflected in the overall organization and implementation of educational work in all kindergartens in the Republic of Croatia" (National Curriculum for...,2014, 32). Based on the National Curriculum for Early and Preschool Education, a kindergarten curriculum is created, the characteristics of which are as follows:

- "integrated (all areas of child development covered into one unit)

- developmental (the nature of the curriculum is developmental, open and dynamic)

- humanistic (starts from the child and encourages the development of its potentials)

- constructivist and co-constructivist (learning as creation, i.e. construction and co-construction of knowledge)" (National Curriculum for...,2014, 41$43)$.

The current preschool curriculum in the Republic of Croatia, within the Objectives of the National Curriculum for Early and Preschool Education, presents two basic goals of preschool education:

- "Ensuring child welfare

- Comprehensive development, education and learning of the child and development of competencies" (National Curriculum for...,2014, 24-26).

The first goal, ensuring child welfare, "implies the focus of the planning of educational work on the child and its welfare" (National Curriculum for...,2014, 24). This goal emphasizes special objectives:

- "personal, emotional and physical welfare

- educational welfare

- social welfare" (National Curriculum for...,2014, 24-26).

Within the Personal, emotional and physical welfare, the goals that determine the moral development and upbringing of a child are:

- "self-acceptance of the child (non-suppression of emotions, acceptance of oneself) 
- self-esteem and self-awareness of the child

- the ability to temporarily put aside meeting its needs

- development of the child's identity (personal and social)

- readiness of the child to make decisions related to its activities

- development of independence of thinking and acting

- assessing the possible consequences of its actions, i.e. considering how to achieve them" (National Curriculum for..., 2014, 24-25).

Within the Educational welfare, the goals that determine the moral development and upbringing of the child are:

- "awareness of the process of one's own learning, managing it and gradually taking responsibility for that process" (National Curriculum for..., 2014, 25).

Within the Social welfare, the goals that determine the moral development of the child relate to interpersonal (social) functioning and development of social competencies, and these are:

- "understanding and acceptance of others and their differences (arising from religious, racial, national, cultural and other differences or special needs)

- compliance with patterns, rules, norms and requirements of the social group / community

- establishing, developing and maintaining a quality relationship with other children and adults

- active participation, negotiation and constructive resolution of conflict situations

- joint (coordinated) activity of the child with others (children and adults)

- ethics, solidarity and tolerance of the child in communication with others

- the ability to adapt the child to new, changing situations and circumstances (flexibility and adaptability)

- perception of oneself as an important part of the community / environment

- the feeling of acceptance and belonging

- perception of oneself as a member of the community who has the opportunity to contribute to the community

- responsible behaviour of the child towards itself and others" (National Curriculum for..., 2014, 25-26).

The second goal highlighted in the curriculum, Comprehensive development, education and learning of the child and development of competencies, "is based on understanding the child as a whole being and accepting the integrated nature of learning in the organization of educational work in kindergarten" (National 
Curriculum for..., 2014, 26). Within this goal, we recognize the principles of educational work, which should contribute to the development of competencies:

- 'children's competencies are developmental, not static

- children's competencies are assessed as a whole, not separately from others

- children's competencies are observed within the developmental possibilities of each child separately, and not according to their age" (National Curriculum for..., 2014, 26).

The Curriculum pays special attention to the development of competencies that are the backbone of the development of all other competencies - "the development of self-esteem, self-confidence and a positive image of the child about itself" (National Curriculum for...,2014, 27). The Objectives of the National Curriculum for Early and Preschool Education also highlights the Key competencies for lifelong learning. Moral development and upbringing of children is directly related to two:

- "social and civic competence

- cultural awareness and expression" (National Curriculum for...,2014, 29-30).

In order to better concretize and compare the data, the goals of preschool education with the purpose of moral development in the mentioned preschool programmes (curricula) are presented in a table. As we can see below (Table 1), the selected basic goals of preschool programmes (curricula) in the Republic of Serbia and the Republic of Croatia with the purpose of moral development of preschool children are presented differently in all three programme concepts. All three preschool programmes (curricula) belong to the category of humanistic valueoriented preschool programmes (curricula), which implies a clear orientation towards the child. 
Table 1. Objectives in preschool programmes (curricula) in the Republic of Serbia and the Republic of Croatia with the purpose of moral development of preschool children

\begin{tabular}{|c|c|c|c|c|c|c|}
\hline \multicolumn{4}{|c|}{ OBJECTIVES IN THE REPUBLIC OF SERBIA } & \multicolumn{3}{|c|}{$\begin{array}{l}\text { OBJECTIVES IN THE } \\
\text { REPUBLIC OF CROATIA }\end{array}$} \\
\hline $\begin{array}{l}\text { General Foundations of the } \\
\text { Preschool Programme (2006) }\end{array}$ & \multicolumn{3}{|c|}{$\begin{array}{c}\text { Preschool curriculum framework- } \\
\text { Years of Ascent (2018) }\end{array}$} & \multicolumn{3}{|c|}{$\begin{array}{l}\text { National Curriculum for Early and } \\
\text { Preschool Education (2014) }\end{array}$} \\
\hline $\begin{array}{c}\text { COMMON } \\
\text { EDUCATIONAL GOALS } \\
\text { IN BOTH PROGRAMME } \\
\text { MODELS }\end{array}$ & \multicolumn{3}{|c|}{$\begin{array}{l}\text { GENERAL OBJECTIVES OF THE } \\
\text { CURRICULUM FRAMEWORK }\end{array}$} & \multicolumn{3}{|c|}{$\begin{array}{l}\text { ENSURING CHILD } \\
\text { WELFARE }\end{array}$} \\
\hline $\begin{array}{l}\text { - gaining a positive self- } \\
\text { image } \\
\text { - developing trust in } \\
\text { yourself and others } \\
\text { - encouraging }\end{array}$ & \multicolumn{3}{|c|}{$\begin{array}{l}\text { CHILD-CENTERED GOALS OF } \\
\text { PRESCHOOL EDUCATION: } \\
\text { SUPPORTING THE CHILD'S } \\
\text { WELFARE }\end{array}$} & $\begin{array}{c}\text { Personal, } \\
\text { emotional } \\
\text { and } \\
\text { physical } \\
\text { welfare }\end{array}$ & $\begin{array}{c}\text { Educational } \\
\text { welfare }\end{array}$ & $\begin{array}{l}\text { Social } \\
\text { welfare }\end{array}$ \\
\hline $\begin{array}{c}\text { responsibility } \\
\text { - developing social }\end{array}$ & $\begin{array}{l}\text { Personal } \\
\text { welfare }\end{array}$ & & & \multirow{2}{*}{\multicolumn{3}{|c|}{$\begin{array}{l}\text { - the ability to temporarily put aside } \\
\text { meeting their needs } \\
\text { - development of independence of } \\
\text { thinking and acting; } \\
\text { - assessing the possible } \\
\text { consequences of their actions } \\
\text { taking responsibility for the } \\
\text { process of one's own learning } \\
\text { - compliance with rules, norms and } \\
\text { requirements of the social group } \\
\text { - active participation and } \\
\text { constructive resolution of conflict } \\
\text { situations } \\
\text { - ethics, solidarity and tolerance of } \\
\text { the child in communication with } \\
\text { others } \\
\text { - responsible behaviour of the child } \\
\text { towards itself and others }\end{array}$}} \\
\hline $\begin{array}{c}\text { accordance with the } \\
\text { humane and tolerant } \\
\text { values of a democratically } \\
\text { organized society } \\
\text { - cultivating children's } \\
\text { emotions and nurturing } \\
\text { the relationship of non- } \\
\text { violent communication } \\
\text { and tolerance } \\
\text { - preparing children for } \\
\text { the upcoming transitional } \\
\text { and more complex } \\
\text { periods of life } \\
\text { awareness of the } \\
\text { importance of protecting } \\
\text { and preserving the } \\
\text { natural and social } \\
\text { environment. }\end{array}$ & \multicolumn{3}{|c|}{$\begin{array}{c}\text { - self-regulation as internal } \\
\text { control; the ability to put aside } \\
\text { desires; accepting demands } \\
\text { - emotional competence (control } \\
\text { emotions and understand one's } \\
\text { own and others' emotions) } \\
\text { - dispositions for learning } \\
\text { (perseverance, openness to } \\
\text { cooperation, responsibility) } \\
\text { - resilience to stress and the ability } \\
\text { to take a constructive approach } \\
\text { to problems } \\
\text { - moral values and norms and } \\
\text { the ability of moral reasoning, } \\
\text { fairness and respect for } \\
\text { differences } \\
\text { - altruism (helpfulness, empathy, } \\
\text { tolerance, kindness, solidarity). }\end{array}$} & & & \\
\hline
\end{tabular}




\begin{tabular}{|c|c|c|}
\hline $\begin{array}{l}\text { SPECIAL GOALS FOR } \\
\text { MODEL A AND } \\
\text { MODEL B }\end{array}$ & \multirow{2}{*}{$\begin{array}{l}\text { Key educational competencies } \\
\text { for lifelong learning }\end{array}$} & \multirow{2}{*}{$\begin{array}{c}\text { COMPREHENSIVE } \\
\text { DEVELOPMENT, EDUCATION } \\
\text { AND LEARNING OF THE CHILD } \\
\text { AND DEVELOPMENT OF } \\
\text { COMPETENCIES }\end{array}$} \\
\hline $\begin{array}{l}\text { - getting to know and } \\
\text { understanding the rules } \\
\text { of behavior in the group }\end{array}$ & & \\
\hline $\begin{array}{l}\text { and building basic moral } \\
\text { norms } \\
\text { - learning to recognize } \\
\text { and respect the needs and } \\
\text { feelings of others } \\
\text { - developing friendly and } \\
\text { cooperative relationships }\end{array}$ & $\begin{array}{c}\text { - social and civic competencies } \\
\text { - cultural awareness and } \\
\text { expression. }\end{array}$ & $\begin{array}{l}\text { Key competencies } \\
\text { for lifelong learning }\end{array}$ \\
\hline $\begin{array}{l}\text { with peers and adults } \\
\text { - forming a personality } \\
\text { that is guided by human } \\
\text { values and aspirations. }\end{array}$ & & $\begin{array}{l}\text { - social and civic competence } \\
\text { - cultural awareness and expression. }\end{array}$ \\
\hline
\end{tabular}

The first programme document in the Republic of Serbia, General Foundations of the Preschool Programme, is based on a humanistic understanding of the nature of the child and its complete (spiritual and physical) development, starting from the child's needs and development potentials. In this document, the child is recognized as a potential of society. The essential determinant of the programme is that the child is a value in itself. The starting points for the development of this programme are also pedagogical and psychological knowledge about the child's development and learning.

The second current programme document in the Republic of Serbia, Preschool curriculum framework - Years of Ascent, has a humanistic value orientation, since it starts from the child and its needs. The programme sees the child as a complete being who is rich in potentials. It is based on modern theoretical assumptions about childhood, learning and development of children at an early age, but also on the tradition and humanistic values of our society, integrated approach to care, upbringing and education, respecting the age specifics of the child and the leading role of play in learning and development.

The National Curriculum for Early and Preschool Education in the Republic of Croatia also has a humanistic value orientation, because it is child-oriented, starts from the child and encourages the development of its potentials. The curriculum is based on the modern understanding of childhood and the child as a whole being rich in potentials. We can say that there are identical value orientations of these preschool programmes (curricula), because their focus is on the child.

The goals of the preschool programme in the Republic of Serbia, in General Foundations of the Preschool Programme, with the purpose of moral development of the preschool child, are presented through common educational goals (Model A and Model B), as well as through special goals for these models. Model A and 
Model B have their general (basic) goals from which specific goals are derived. Within the educational goals in both models of the programme, we can conclude that the moral development of the child permeates through seven, out of a total of ten goals. The goal that directly relates to the moral development and upbringing of children is the development of social and moral values in accordance with the humane and tolerant values of a democratically organized society sensitive to family, cultural and religious differences. In other goals, moral development is recognized through socio-emotional development, because morality is closely related to the process of socialization of the child's personality, and moral education is inseparable from socio-emotional development.

There are goals that contribute to the formation of a child as a healthy individual who will have a positive attitude towards itself and others. The goals related to a healthy and positive attitude of the child towards the natural environment, as well as a caring attitude towards the social environment are emphasized. The goals that contribute to the moral upbringing of the child are reflected in the quality of the child's preparation for school, as well as for life and everything that awaits it. When starting school, a child's moral development is still developing. The child continues to learn and adopt new patterns of behavior, through the various contents that the school offers. The goals of moral development and upbringing of children in special goals for Model $A$ are recognized through two areas of development (Getting to know and mastering yourself and Developing relationships and knowledge about others). Moral development is also reflected in the special goals for Model $B$. We see that moral development in Model A and Model B is recognized latently, through a complementary presentation of the socio-emotional aspect of the child's personality.

The goals of the preschool programme in the Republic of Serbia, with the purpose of moral development of the preschool child in the Preschool curriculum framework - Years of Ascent, are presented through the General goals of the Curriculum Framework and through the Goals aimed at the child (supporting the child's welfare). Within the general goals, the moral development of children is not stated directly, but is recognized through socio-emotional development. Objectives have been set related to building self-confidence, mutual respect and nurturing friendship, developing resilience, perseverance as well as recognizing and respecting different cultures. The general goals defined in this way bring the child to the forefront as an authentic, active and proactive social subject that is part of a broader social context. As already mentioned, within the Goals aimed at the child: supporting the child's welfare, moral development is recognized through the personal, active and social welfare of the child. All types of welfare relate to 
the overall development of children, which indicates the key orientation of the programme, and that is the focus on the child as a whole being. Moral development is directly stated in this programme document as a goal within the social welfare as the development of moral values and norms and the ability of moral reasoning, fairness and respect for differences. Moral development is directly related to the social welfare of the child, since socialization is inseparable from the moral education of children, as they, as social beings, live and grow up in a social environment. Socialization is a prerequisite for the child's integration into the community. The social environment provides patterns of moral behavior through the interaction of the child and society, and is directly related to the moral education of the child. The Goals aimed at the child: supporting the child's welfare, highlights the key educational competencies for lifelong learning in preschool education. We have already stated that the two competencies are directly related to the moral development and upbringing of the child - social and civic competencies and cultural awareness and expression. These competencies are developed and improved continuously, throughout the entire preschool period, through the closeness of children, adults and peers, through joint activities and actions. They are achieved in children by developing mutual respect and acceptance, agreement, cooperation and support among children, respect and appreciation of differences, etc. The development of these competencies contributes to the development of morals and right moral values in preschool children.

The goals of the preschool programme in the Republic of Croatia with the purpose of moral development of the preschool child in the National Curriculum for Early and Preschool Education, are presented through two goals that clearly indicate the goal orientation of this curriculum, which is the child. Within the first goal, ensuring child welfare, moral development permeates all three welfares. Personal, emotional and physical, educational and social wellfare indicate the encouragement of the child's overall development. Moral development is encouraged within the socio-emotional development, which defines children as social beings who by their participation affect the environment. The second goal, Comprehensive development, education and learning of the child and development of competencies, fully perceives the child's personality and does not separate the child's development, upbringing and learning. This goal highlights competencies for lifelong learning. As already pointed out, the two competencies that are directly related to the moral development and upbringing of the child are social and civic competence and cultural awareness and expression. The development of these competencies helps the child's selfinitiative in play and work, encourages responsible behavior and tolerant attitude towards others, develops interpersonal and intercultural cooperation, self-esteem 
and respect for others, as well as mutual assistance and acceptance of differences (culture, language, customs, traditions). By developing the stated competencies, the child accepts moral norms and gradually builds attitudes. The child as an individual thus builds a personality that is accepted in a social community in which certain rules prevail, and fits into the context of society.

By descriptive analysis and tabular comparative presentation of the goals of preschool programmes (curricula), with the purpose of moral development, we can notice that there are similarities between the two programme documents, the Preschool curriculum framework - Years of Ascent (2018) and the National Curriculum for Early and Preschool Education (2014). Both have the same goal of supporting the child's welfare. Both documents, through the support of child welfare, single out three types of welfare, which are essentially the same, but are differently formulated. In the Preschool curriculum framework - Years of Ascent, there is one goal that is directly related to the moral development and upbringing of the child. The moral development of the preschool child in the Republic of Croatia can be found within the first goal (Ensuring child welfare), while in the Republic of Serbia we can find it within the goal that includes supporting the child's welfare. The goals of moral development in both documents are mostly recognized indirectly. Both programme documents pay special attention to the development of children's key competencies for lifelong learning. Moral development is directly related to two competencies, which are identical and have a similar linguistic formulation. We also notice that these two programmes (curricula) are very similar in content and structure.

\section{CONCLUSION}

Through descriptive analysis and a tabular comparative presentation of the goals of moral development and upbringing of children in preschool programmes (curricula) in the Republic of Serbia and the Republic of Croatia, we notice that in all three preschool programmes (curricula) there are goals related to moral development and upbringing of the child, but that we do not find in them specifically singled out goals of moral development and upbringing, but instead recognize them within other aspects of child development, general goals, goals of supporting child welfare, jointly determined goals, or individual goals.

In the General Foundations of the Preschool Programme (2006), analyzing the common educational goals, as well as specific goals in both programme models, we can conclude that moral development is recognized in this programme document and is mostly presented indirectly (through socio-emotional development). This 
document differs from the other two programmes in the Republic of Serbia and the Republic of Croatia in its structure. The Preschool curriculum framework Years of Ascent, and the General Foundations of the Preschool Programme have one goal each, which is directly related to the moral development of the child. The difference between the three documents is that the programmes in the Republic of Serbia clearly define general goals, while in the Republic of Croatia there are no singled out general goals. We also note that the Preschool curriculum framework Years of Ascent and National Curriculum for Early and Preschool Education have more elaborate goals related to moral development, compared to the General Foundations of the Preschool Programme, but we know that this programme has accompanying methodical instructions in which the goals and tasks of the moral development of the preschool child are concretized.

Based on the presented data, we can conclude that in preschool programmes (curricula) in the Republic of Serbia and the Republic of Croatia, the goals of moral development and upbringing of young children derive from the general goals of upbringing. 


\section{REFERENCES}

1. Antonijević, R. (2013). Opšta pedagogija. Beograd: Institut za pedagogiju i andragogiju.

2. Kamenov, E. (1997). Metodika: metodička uputstva za model B Osnova programa predškolskog vaspitanja i obrazovanja dece od tri do sedam godina, Deo 1. Novi Sad: Tampograf.

3. Nacionalni kurikulum za rani i predškolski odgoj i obrazovanje (2014). [National Curriculum for Early and Preschool Education] Zagreb: Ministarstvo znanosti, obrazovanja i sporta RH.

4. Osnove programa predškolskog vaspitanja i obrazovanja - Godine uzleta (2018). [Preschool curriculum framework - Years of Ascent] Beograd: Prosvetni pregled.

5. Pijanović P. et al. (1996). Pedagoški leksikon. Beograd: Zavod za udžbenike i nastavna sredstva.

6. Pravilnik o Opštim osnovama predškolskog programa (2006). [Bylaw on Preschool Programme Fundamentals] Beograd: Prosvetni pregled. 


\section{GILJEVI U SUVREMENIM PREDŠKOLSKIM PROGRAMIMA (KURIKULUMIMA) U REPUBLICI SRBIJI I REPUBLICI HRVATSKOJ U FUNKCIJI MORALNOGA RAZVOJA DJETETA PREDŠKOLSKE DOBI}

\section{SAŽETAK}

U ovome radu analiziramo i kompariramo sadržaj aktualnih predškolskih programa (kurikuluma) u Republici Srbiji i Republici Hrvatskoj, kroz podroban prikaz ciljeva moralnoga razvoja i odgoja djece predškolske dobi u njima. Istraživanje je izvedeno primjenom opisne metode, a u radu je primijenjen postupak analize sadražaja. Rezultati istraživanja, prikazani tekstualno i tablično, ukazuju da u Republici Srbiji i Republici Hrvatskoj u svim trima predškolskim programima (kurikuluma) postoje ciljevi koji se odnose na moralni razvoj i odgoj djeteta, ali u njima ne postoje posebno izdvojeni ciljevi moralnoga razvoja već ih prepoznajemo u okviru sfera/aspekata dječjega razvoja, zajednički određenih ciljeva, općih ciljeva, ciljeva potpore dobrobiti djeteta ili pojedinačnih ciljeva.

Ključne riječi: predškolski program (kurikulum), ciljevi moralnoga razvoja i odgoja, dijete. 